\title{
Abundance and behavioural ecology of the blenny Ophioblennius trinitatis (Teleostei: Blenniidae) at an oceanic archipelago of Brazil (Atlantic)
}

\author{
Paulo R. Medeiros ${ }^{1,2}$, Danilo P. Rada ${ }^{2}$, Ricardo S. Rosa ${ }^{2}$ \\ ${ }^{1}$ Unidade Acadêmica de Ciências Exatas e da Natureza, Universidade Federal de Campina Grande, 58900-000, Cajazeiras, \\ PB, Brazil. E-mail: medeirospr@gmail.com \\ ${ }^{2}$ Centro de Ciências Exatas e da Natureza, Universidade Federal da Paraíba, Cidade Universitária, 58059-900 João Pessoa, \\ PB, Brazil.
}

\begin{abstract}
Summary: Local patterns of fish density, microhabitat use, feeding behaviour, bite rate, territory area and agonistic interactions were recorded for Ophioblennius trinitatis at an oceanic archipelago (southwestern Atlantic). Rugosity, number of crevices and benthic diversity positively predicted the distribution of $O$. trinitatis. Turf algae was the preferred food item at all sites, but given its high availability inside and outside territory boundaries, it did not seem to be a limiting factor on the density of this blenny, as opposed to substrate heterogeneity. Bite rate was higher in the afternoon and for smaller individuals (juveniles). Territory size showed local variation and, although larger territories may be an effect of density-dependent conditions (more available space in low-density areas), we propose that individuals expand territories to compensate for residing in areas of lower quality (i.e. of low structural complexity). Larger individuals defended larger territories and residents responded differently to intruders, with higher rates of agonistic interactions towards potential competitors. Higher agonistic rates were also observed in larger territories and at low-complexity sites.
\end{abstract}

Keywords: behaviour; Blennidae; Brazil; density; territory; microhabitat.

La abundancia y la ecología del comportamiento del blenny Ophioblennius trinitatis (Teleostei: Blenniidae) en un archipiélago oceánico de Brasil (Atlántico)

Resumen: En este trabajo se han estudiado las pautas en la densidad, la utilización del micro hábitat, el comportamiento alimentario, las tasas de mordisqueo, la superficie del territorio y las interacciones agonísticas de Ophioblennius trinitatis en un archipiélago oceánico del SO Atlántico. Los mejores predictores de la distribución de $O$. trinitatis fueron la rugosidad, el número de grietas y la diversidad bentónica. El turf algal es el alimento preferido de este pez en todos los lugares, pero dada su elevada disponibilidad, dentro y fuera de los territorios, no pareció ser un factor limitante para este blénido como lo fue la heterogeneidad del substrato. La tasa de mordisqueo resultó ser más elevada entre los peces pequeños (juveniles) y especialmente por la tarde. La superficie del territorio presentó notables variaciones locales y, a pesar de que los territorios mayores pueden ser el resultado de un efecto denso-dependiente (al haber más espacio disponible en la zonas con densidades bajas), proponemos que los individuos expanden su territorio para compensar la baja calidad ambiental de ciertas zonas (una baja complejidad estructural). Los ejemplares mayores defendían territorios más extensos y respondían de manera diferente ante los intrusos, con una mayor tasa de interacciones agonísticas hacia los potenciales intrusos. Las interacciones agonísticas también fueron más elevadas en los territorios más amplios y con una baja complejidad.

Palabras clave: comportamiento; Blennidae; densidad; territorio; micro hábitat.

Citation/Como citar este artículo: Medeiros P.R., Rada D.P., Rosa R.S. 2014. Abundance and behavioural ecology of the blenny Ophioblennius trinitatis (Teleostei: Blenniidae) at an oceanic archipelago of Brazil (Atlantic). Sci. Mar. 78(2): 203212. doi: http://dx.doi.org/10.3989/scimar.03979.30G

Editor: A. Garcia-Rubies.

Received: October 29, 2013. Accepted: March 7, 2014. Published: May 30, 2014.

Copyright: (0) 2014 CSIC. This is an open-access article distributed under the Creative Commons Attribution-Non Commercial Lisence (by-nc) Spain 3.0.

\section{INTRODUCTION}

The genus Ophioblennius comprises at least five highly related Atlantic blennies (see Muss et al. 2001), one of which, Ophioblennius trinitatis Miranda-Ribeiro 1919, is exclusively found on the Brazilian coast and its associated oceanic islands, a distinct biogeographic province (Floeter and Gasparini 2000, 2001). 
Ophioblennius species are diurnally-active primary consumers, residing within restricted and permanent home ranges (i.e. territories), and are hostile in defending resources from intruder fishes (Nursall 1977, Humann and DeLoach 2002, Mendes 2006). Adults are primarily observed in shallow consolidated reef areas, whereas juveniles have been reported at depths of up to 53 m (Bath 1990, Mendes 2007).

Previous studies showed that Ophioblennius species contribute greatly to the overall abundance (Randall 1996, Medeiros et al. 2010a) and biomass (Labelle and Nursall 1992) of site-attached fishes on both coral and rocky reefs of the Atlantic Ocean. Furthermore, given their territorial habits, which potentially influence the distribution of other fishes, and their role in linking energy from primary producers to carnivores (Labelle and Nursall 1992), they are of great ecological importance to the overall reef community.

In recent decades, due to a surge in the number of tropical reef studies carried out in the southwestern Atlantic, many species formerly recognized as Caribbean-equivalents have been resurrected from synonym (Guimarães and De Bacellar 2002, Moura et al. 2001, Rocha and Rosa 2001, Rocha 2004), including O. trinitatis (Muss et al. 2001). In fact, intraspecific variations in $O$. trinitatis along the Brazilian coast and oceanic islands suggest that this taxon needs a thorough revision. Although similarities in the ecology of related Caribbean and Brazilian fishes have been acknowledged in the past, more recent investigations suggest that the ecological and behavioural processes differ substantially between counterpart species from these two provinces (see Floeter and Gasparini 2000 for a review). Nonetheless, most of what is known nowadays on the ecological requirements and general habits of $O$. trinitatis is actually an extrapolation from what is known for $O$. atlanticus studied in the Caribbean (e.g. Nursall 1977, 1981, Rylander and Koster 1982, Nursall 1989, Marraro and Nursall 1983, Nursall and Turner 1985, Labelle and Nursall 1985, 1992, Muss et al. 2001, but see Mendes 2006, 2007). Therefore, direct ecological and behavioural studies on $O$. trinitatis are an important means of supporting and/or contesting Caribbean-based findings.

In this paper, local patterns of abundance and microhabitat use, in addition to several behavioural traits (i.e. feeding behaviour, bite rate, territory size and agonistic interactions) were investigated for $O$. trinitatis at an oceanic archipelago of the southwestern Atlantic. Specifically, to test the ecological implications of spatial variation in fish density, we hypothesized that differences in spatial distribution are driven by differences in microhabitat characteristics. Regarding behavioural traits, the following hypotheses were tested, locally and spatially (i.e. among sites): 1) smaller individuals have higher bite rates due to a proportionally higher energy demand, typical of juveniles; 2) larger territories are observed at low-density sites due to the increased space availability and relaxed competition; 3) larger fish are able to defend larger territories; 4) potential competitors (i.e. fishes sharing feeding habits) are most likely to be involved in agonistic interactions than non- competitors; 5) larger individuals are more aggressive than smaller ones; and 6) agonistic interactions are higher at sites of high habitat complexity, given the increased competition for these optimal sites.

\section{MATERIALS AND METHODS}

\section{Study area and sampling procedures}

The study was conducted at Fernando de Noronha archipelago, an oceanic marine protected area of the southwestern Atlantic, located $360 \mathrm{~km}$ off the Brazilian coast (Fig. 1). The study was conducted between October and November 2009, always during the day, at four sites (Raquel, Sueste, Atalaia and Porto) (Fig. 1). General substratum characteristics of each site are as follows: Raquel is dominated by rocky pavements colonized by dense colonies of fleshy macroalgae and a high proportion of encrusting coralline algae. Sueste is dominated by reef flats with high proportions of sand and limestone, interspersed with rocky reefs, where turf algae and fleshy algae predominate. Atalaia is a small, protected reef area, where sandy bottoms blend with a reef terrace and somewhat high proportions of fleshy and coralline algae are observed. Porto is mainly a reef flat dominated by limestone and macroalgae, interspersed with rocky reefs where macroalgae and coralline are abundant (Eston et al. 1986).

Density of $O$. trinitatis individuals was determined using underwater visual census (UVC) techniques on $2 \times 2 \mathrm{~m}$ quadrates on consolidated substrates in each area $(\mathrm{n}=10$ quadrates per site). All surveys were conducted at depths of less than $80 \mathrm{~cm}$. Given the distinct depth distributions of the two recognized colour morphs (see Mendes 2006, Rangel and Mendes 2009), observations of the present study included mostly, if not solely, $O$. trinitatis type 1 (typically the darker, adult individuals). Size of quadrates was chosen based on a previous study (i.e. Mendes 2007). Each sample location was randomly chosen by dropping a lead weight to mark the centre of the quadrate. A one-minute period was left for the fish to get used to the diver's presence and to return after possible initial disturbances and, subse-

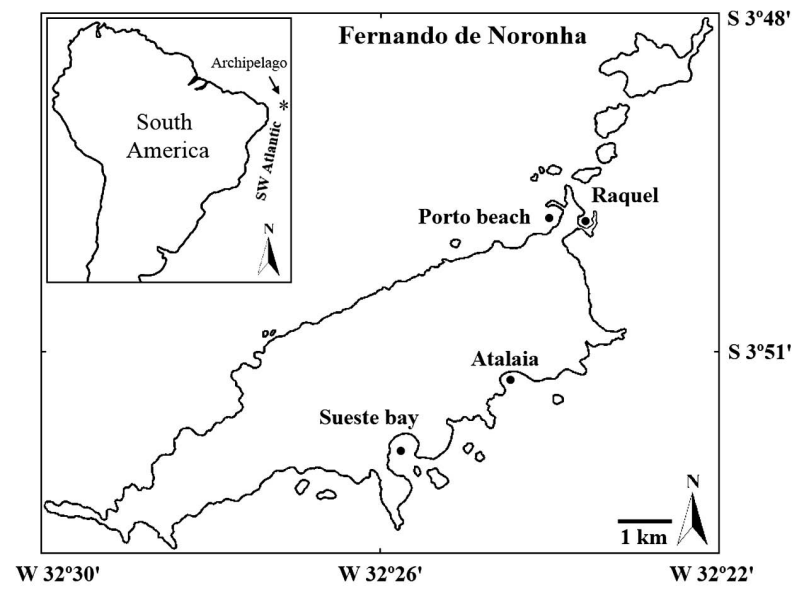

Fig. 1 - Location of study sites at Fernando de Noronha archipelago, southwestern Atlantic. 
quently, the diver spent 5 minutes counting all $O$. trinitatis individuals inside and within up to $0.5 \mathrm{~m}$ above the quadrate. Simultaneously, fishes wandering within the territory boundaries were also quantified in order to determine the composition and abundance of potential intruders. Care was taken to avoid quantifying the same individuals going in and out of the quadrate area.

Following fish counts, rugosity, depth and benthic composition were assessed in each quadrate. A 1-mlong chain was used to assess the physical complexity (rugosity) of the substrate (Luckhurst and Luckhurst 1978). The chain was positioned on the substrate and then adjusted, so it draped the substrate's irregularities. Rugosity was determined at two non-overlapping locations within each quadrate and, subsequently, a rugosity index was estimated by calculating the ratio of the contoured chain to the linear horizontal distance (i.e. 1 $\mathrm{m})$ and the mean value of the two replicates was used. Number of crevices was assessed by recording the number of holes located within the quadrate that were potentially used as temporary or permanent refuge sites (i.e. that were deeper than $5 \mathrm{~cm}$ and with a diameter $<15 \mathrm{~cm}$ ), and their length. Benthic composition was evaluated using photo-quadrats (Preskitt et al. 2004) by taking a photograph in each quadrate area. Photographs were analysed by randomly plotting 50 points and estimating the relative proportions of six benthic categories (i.e. turf algae, macroalgae, coralline algae, live coral, sand and uncolonized pavement) using the coral point count with Excel extension software (CPCe 3.6) (Kohler and Gill 2006).

Feeding behaviour, agonistic interactions and territory size of $O$. trinitatis were quantified simultaneously using focal animal procedures (Lehner 1996) for 40 individuals for 5 minutes each (10 focal adult individuals per site; 200 minutes of total observation). Density estimates and behavioural evaluations were made on separate events. Bite rate, that is, the number of times an individual bit on the substrate per minute, was quantified for each focal individual. During focal observations, benthic categories where bites were directed (same as described above) were distinguished, and size of each focal individual (total length: TL) was visually estimated. To test the effect of time on bite rate, focal observations were evenly spread between 10 am and $3 \mathrm{pm}$. For each focal individual we also recorded the number of agonistic interactions between the focal $O$. trinitatis (resident fish) and an intruder fish, and whether this was an intruder-directed interaction (i.e. the resident $O$. trinitatis attacking an intruder fish) or a resident-directed interaction (i.e. the resident $O$. trinitiatis being attacked by an intruder fish). Territory size was estimated by visually discerning and placing lead weights at the outermost locations visited by the focal fish to delimit its territory as a polygon. The longest diameter and the perimeter were measured and territory size was later calculated by drawing their positions and, using a compass and a protractor, drawing right-angle triangles $\left(90^{\circ}\right)$ inside the polygon, which had their areas calculated and combined to estimate overall territory size (Morgan and Kramer 2004; Medeiros et al. 2010b).

\section{Data analysis}

One-way ANOVAs (type III sum of squares) were used to verify spatial differences (i.e. among sites) of rugosity, number of crevices and fish density (log-transformed). Post-hoc Tukey HSD tests were used in case of significant $F$ values. A one-way MANOVA (type III sum of squares; Pillai's trace test statistic) followed by Tukey's HSD test was used to verify spatial differences in the density of intruder fishes. Prior to running the analyses, normality and homogeneity of data were tested via KolmogorovSmirnov and Levene tests, respectively (Sokal and Rohlf 1995), and when necessary data were transformed and re-tested.

The contribution of each benthic category to the substrate of each site was evaluated by a principal components analysis (PCA), using arcsine square roottransformed data of benthic proportions. The first two factors were interpreted (in all cases Eigenvalues $>1.5$ ) and the relative importance of each significant variable was inferred. Additionally, to test the effects of spatial variability and microhabitat covariates on density of $O$. trinitatis, factor scores from the PCA were used in a multivariate ANCOVA design (all effects model). In this analysis, density of $O$. trinitatis was entered as a dependent variable, study site as a categorical predictor and rugosity, number of crevices, depth, substrate diversity (Simpson's index) and benthic composition (factor scores from principal components 1 and 2) as habitat covariates.

Spatial variation of behavioural traits (bite rate, territory size and agonistic interactions) were also assessed by means of one-way ANOVAs, similarly as described above. In order to determine feeding preferences relative to food availability in the environment, we used Ivlev's electivity index (Ivlev 1961), $E=\left(r_{i}\right.$ $\left.-p_{i}\right)\left(r_{i}+p_{i}\right)^{-1}$, where $E$ is the electivity index and $r_{i}$ and $p_{i}$ are the relative proportions of the $i$ category in the diet $(r)$ and in the environment $(p)$, respectively. This index ranges from -1 to 1 , where positive values indicate a preference, negative values avoidance or inaccessibility, and values close to zero suggest an expected random feeding.

Simple linear regressions were used to test relationships between bite rate and fish size, territory size and fish size, rate of agonistic interactions and fish size, rate of agonistic interactions and territory size, and rate of agonistic interactions and rugosity. Finally, bite rate data were pooled across two periods (morning and afternoon) and a pairwise t-test was conducted. All statistical analyses were conducted on Statistica and Canoco softwares.

\section{RESULTS}

\section{Relationship between fish density and habitat features}

Number of Ophioblennius trinitatis individuals per $\mathrm{m}^{2}$ pooled across the four study sites was (mean $\pm \mathrm{SE}$ ) $1.14 \pm 0.86$. A significant difference in density was ob- 


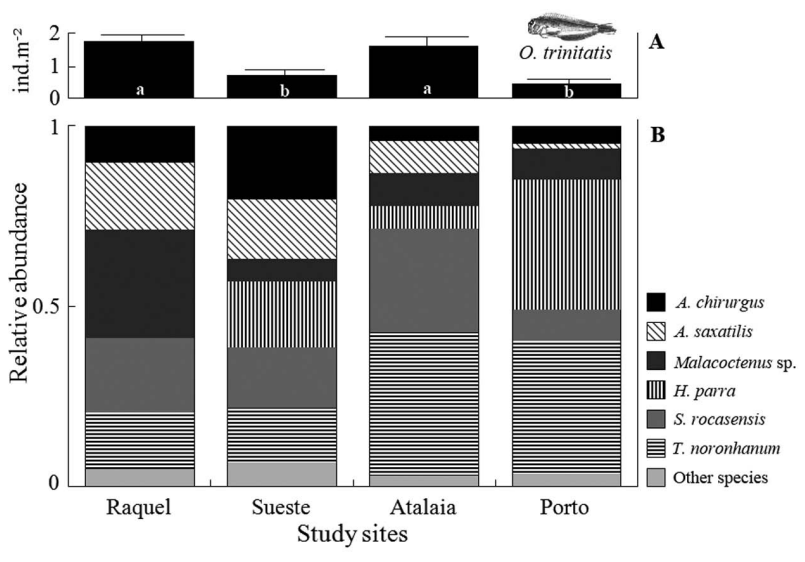

Fig. 2 - Density $($ mean \pm SE) of O. trinitatis (A) and relative abundances of intruders (B) at four study sites. Significant differences between sites (i.e. between columns) are assigned by different letters on the upper panel. served among sites (ANOVA, $\mathrm{F}_{3,36}=11.79$, $\mathrm{p}<0.0001$ ), with Raquel and Atalaia showing higher values than Sueste and Porto (Fig. 2A).

Pooled across all sites, rugosity and number of crevices values were $($ mean $\pm \mathrm{SE})$, respectively, $1.31 \pm 0.02$ and 7.68 \pm 3.3 , with no significant spatial differences observed (ANOVA, $\mathrm{F}_{3,36}=1.53 ; \mathrm{p}>0.05$ ) (ANOVA, $\left.\mathrm{F}_{3,36}=1.12 ; \mathrm{p}>0.05\right)$. Benthic composition was categorized and evaluated by a PCA (biplots shown in Fig. 3A). The first two PCA factors generated for Raquel cumulatively explained $71.5 \%$ of the variation in benthic composition. Factor 1 (37.4\% of the variation) described an increasing proportion of macroalgae, coralline algae and uncolonized pavement, and a decreasing proportion of live coral. Factor $2(34.1 \%)$ described an increasing proportion of turf algae and a decreasing proportion of live coral. At Sueste, the first two factors explained $67.8 \%$ of the variation. Factor $1(42.2 \%)$ de-

A
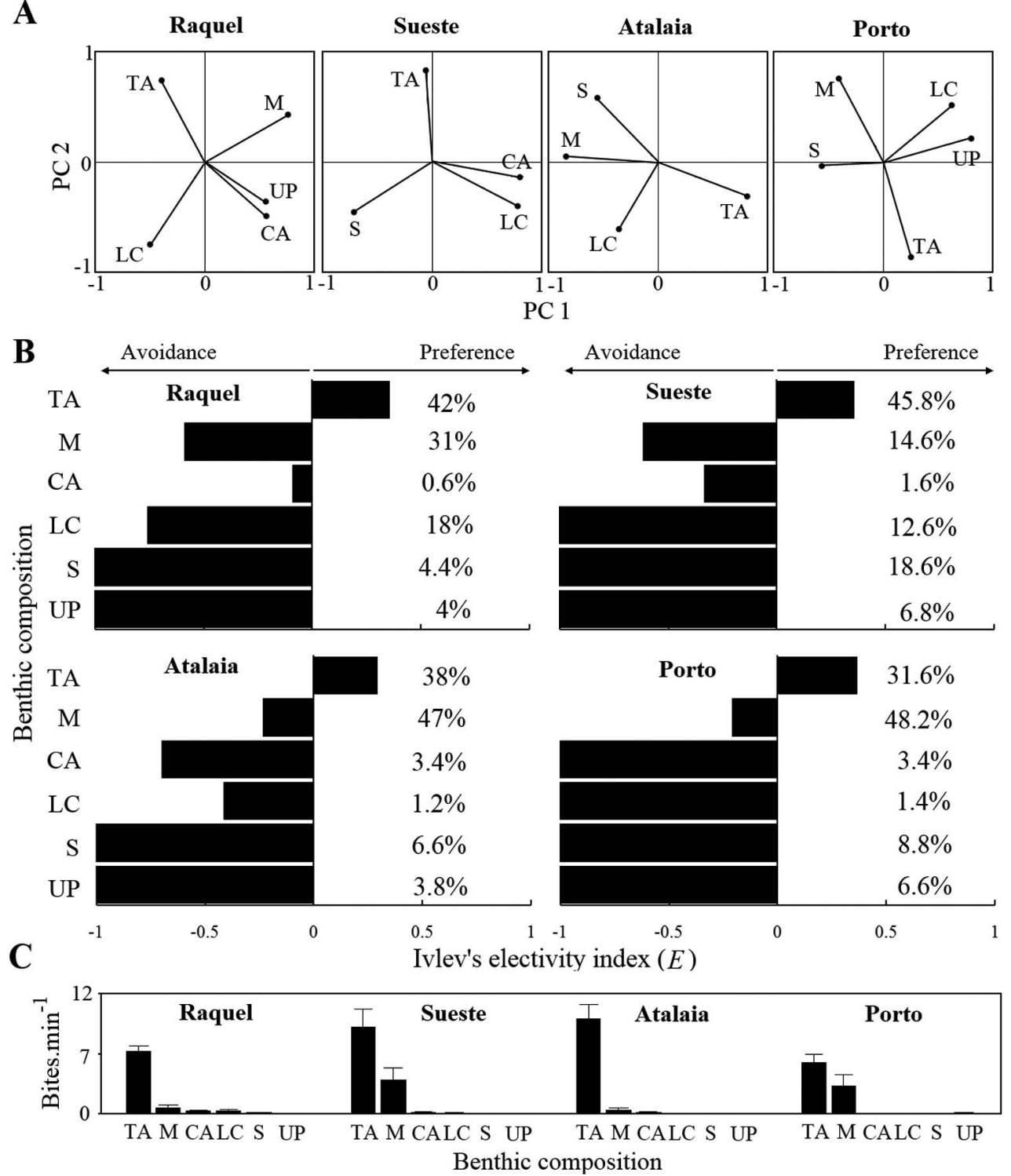

Fig. 3 - A, PCA biplots of factors 1 and 2, showing central positions of factor scores from significant benthic categories. B, Ivlev's electivity index for feeding preferences of $O$. trinitatis. Mean percent cover of each category from each site indicated. c) Bite rates (mean \pm SE) of $O$. trinitatis at six benthic categories. Benthic categories include turf algae (TA), macroalgae (M), coralline algae (CA), live coral (LC), sand (S) and unconsolidated pavement (UP). 
Table 1. - Results of a multivariate ANCOVA design (all effects model) testing the effects of spatial variations in the density of $O$. trinitatis with habitat variables as covariates. Habitat variables included rugosity, number of crevices, depth, substrate diversity (Simpson's index) and benthic composition (using factor scores of principal components 1 and 2). Significant correlations are highlighted as *.

\begin{tabular}{lccc}
\hline Variables and PCA factors & F & d.f. & p \\
\hline Rugosity & 5.10 & 1 & $0.03^{*}$ \\
Number of crevices & 6.78 & 1 & $0.01^{*}$ \\
Depth & 2.20 & 1 & 0.15 \\
Substrate diversity & 3.79 & 1 & $0.04^{*}$ \\
PCA 1 & 1.73 & 1 & 0.20 \\
PCA 2 & 0.54 & 1 & 0.47 \\
\hline
\end{tabular}

scribed an increasing proportion of coralline algae and live coral, and a decreasing proportion of sand. Factor $2(25.6 \%)$ described an increasing proportion of turf algae and a decreasing proportion of sand. At Atalaia, the first two factors explained $69.8 \%$ of the variation. Factor 1 (43.9\%) described an increasing proportion of turf algae, and a decreasing proportion of macroalgae and sand. Factor 2 (25.9\%) described a decreasing proportion of live coral. At Porto, the first two factors explained $69.3 \%$ of the variation. Factor 1 (35.8\%) described an increasing proportion of uncolonized pavement and live coral, and a decreasing proportion of sand. Factor $2(33.5 \%)$ described an increasing proportion of macroalgae and live coral, and a decreasing proportion of turf algae.

ANCOVA results indicated that the density of $O$. trinitatis individuals, albeit marginally, was significantly affected by rugosity, number of crevices and substrate diversity (Simpson's index), whereas water depth and PCA factors had no effect (Table 1).

\section{Feeding behaviour}

Turf algae, macroalgae and sand (Sueste only) were by far the most abundant benthic items (Fig. 3B). Coralline algae showed small percentages and live coral cover was somewhat high at Raquel and Sueste, but very low at Atalaia and Porto. Bite rates were mostly directed towards turf algae and, to a smaller extent, towards macroalgae (Fig. 3C), and regardless of differences in benthic composition among sites, turf algae were the only preferred food item by $O$. trinitatis at all sites, whereas the other items were completely avoided (Fig. 3B).

Bite rate averaged (mean \pm SE) $10.7 \pm 0.71$ bites. $\mathrm{min}^{-1}$ pooled across the four sites, but differed significantly among sites ( $A N O V A, F_{3,39}=3.73$; $p<0.05$ ) due to differences between Raquel and Atalaia (Fig. $4 \mathrm{~A})$. Also, albeit weakly related $\left(\mathrm{r}^{2}=0.14 ; \mathrm{p}<0.05\right)$, bite rate decreased with an increase in the size of individuals, mostly due to higher bite rates being observed for individuals smaller than $5 \mathrm{~cm}$ TL compared with individuals with 6-9 cm TL (Fig. 4B). An increase in bite rate occurred during day hours, with peak rates from 1 to $2 \mathrm{pm}$ (Fig. 4C). Further, with average bite rates of the morning and the afternoon periods pooled separately, a significant difference was observed $($ T-test; $t$-value $=-2.15 ; \mathrm{df}=38 ; \mathrm{p}<0.05)$ (Fig. 4C).
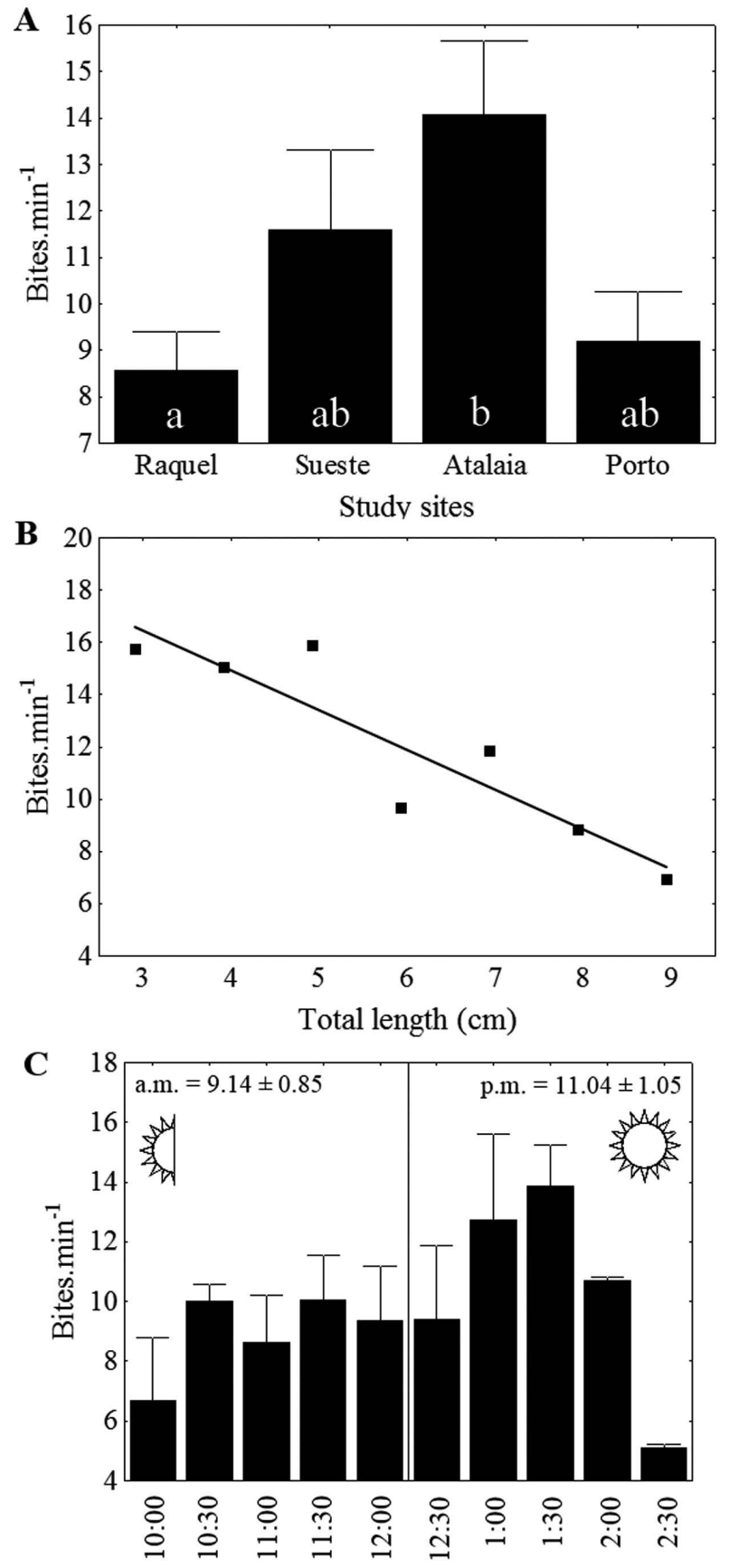

Time of day

Fig. 4 - A, bite rates (mean $\pm \mathrm{SE})$ of $O$. trinitatis at four study sites. $B$, relationship between bite rate $($ mean \pm SE) and fish size. Relationship between bite rate (mean $\pm \mathrm{SE}$ ) and time of day. Significant differences between sites (i.e. between columns) are assigned by different letters on the upper panel.

\section{Territory size and agonistic behaviours}

Pooled across sites, territory size averaged (mean \pm SE) $0.79 \pm 0.09 \mathrm{~m}^{2}$, and differed significantly among sites (ANOVA; $\mathrm{F}_{3,39}=4.80 ; \mathrm{p}<0.01$ ), with higher values observed in Sueste and Porto (Fig. 5A). Territory size showed a weak but significant positive relation with total length of individuals $\left(r^{2}=0.08 ; p<0.05\right)$, suggesting that larger individuals defended larger territories (Fig. 5B). 

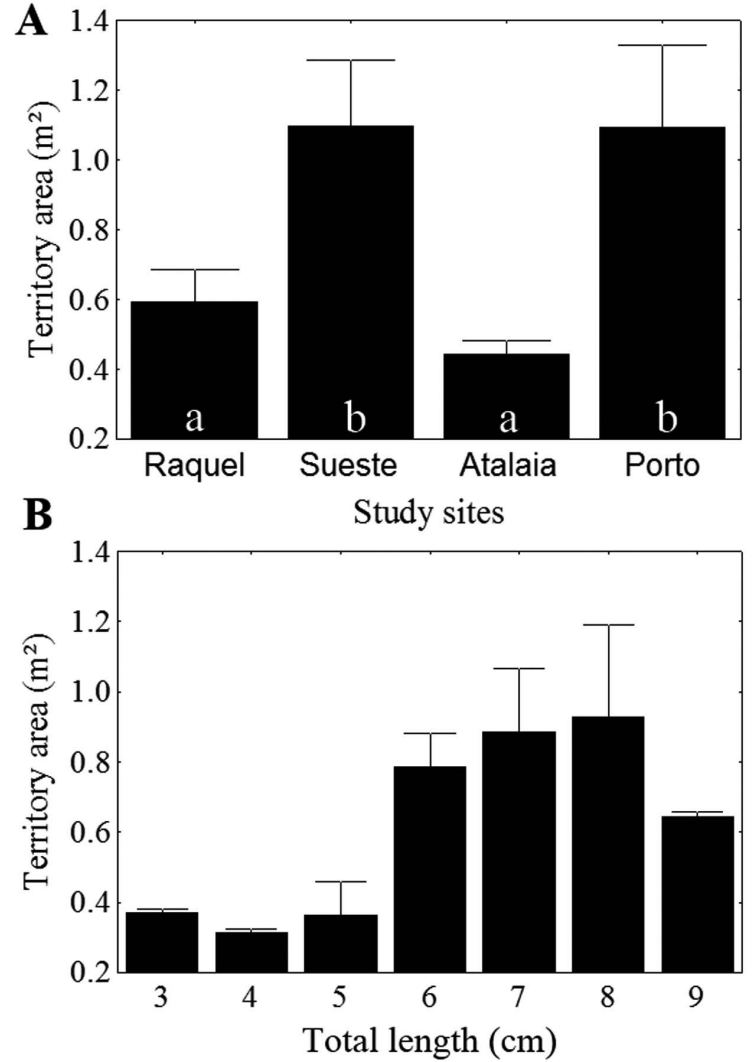

Fig. 5 - A, territory size (mean \pm SE) of $O$. trinitatis at four study sites. B, relationship between territory size $($ mean $\pm \mathrm{SE})$ and fish size. Significant differences between sites (i.e. between columns) are assigned by different letters on the upper panel.
The most common intruders within territories of $O$. trinitatis at all sites were, in decreasing order of importance, the Noronha wrasse Thalassoma noronhanum (Boulenger 1890) (mean abundance \pm SE, 4.45 \pm 3.71 ; relative abundance, 25.2\%), the Rocas Gregory Stegastes rocasensis (Emery 1972) (3.33 $\pm 2.22 ; 18.8 \%)$, sailor's grunt Haemulon parra (Desmarest 1823) (2.53 \pm 2.21 ; $14.3 \%)$, Malacoctenus sp. $(2.4 \pm 2.57 ; 13.6 \%)$, the sergeant major Abudefduf saxatilis (Linnaeus 1758) $(2.15 \pm 3.40 ; 12.2 \%)$ and the doctorfish Acanthurus chirurgus (Bloch 1787) (1.95 $\pm 3.02 ; 11.1 \%$ ) (Fig. 6A). The remaining ten species accounted together for $4.8 \%$ of the recorded intruders: Halichoeres radiatus (Labridae), Sparisoma frondosum (Scaridae), Acanthurus coeruleus (Acanthuridae), Holocentrus adscensionis (Holocentridae), Sparisoma amplum (Scaridae), Sparisoma axillare (Scaridae), Bothus lunatus (Bothidae), Caranx latus (Carangidae), Chromis multilineata (Pomacentridae) and Pseudupeneus maculatus (Mullidae). Density of intruders varied significantly across sites (MANOVA; Pillai's trace $=1.76 ; \quad F_{45,72}=2.26$; $\mathrm{p}<0.001$ ), and the two sites with higher densities of $O$. trinitatis showed higher abundances of A. saxatilis, Malacoctenus sp., S. rocasensis and T. noronhanum (Tukey's HSD test; p<0.05) (Fig. 2B).

Rate of intruder-directed agonistic interactions (see Material and Methods) differed significantly among sites (ANOVA; $\mathrm{F}_{3,39}=3.71 ; \mathrm{p}<0.05$ ), being less common at Atalaia (Fig. 6A). Five intruder species were involved in agonistic interactions, and more than $85 \%$ of the attacks of resident $O$. trinitatis were directed

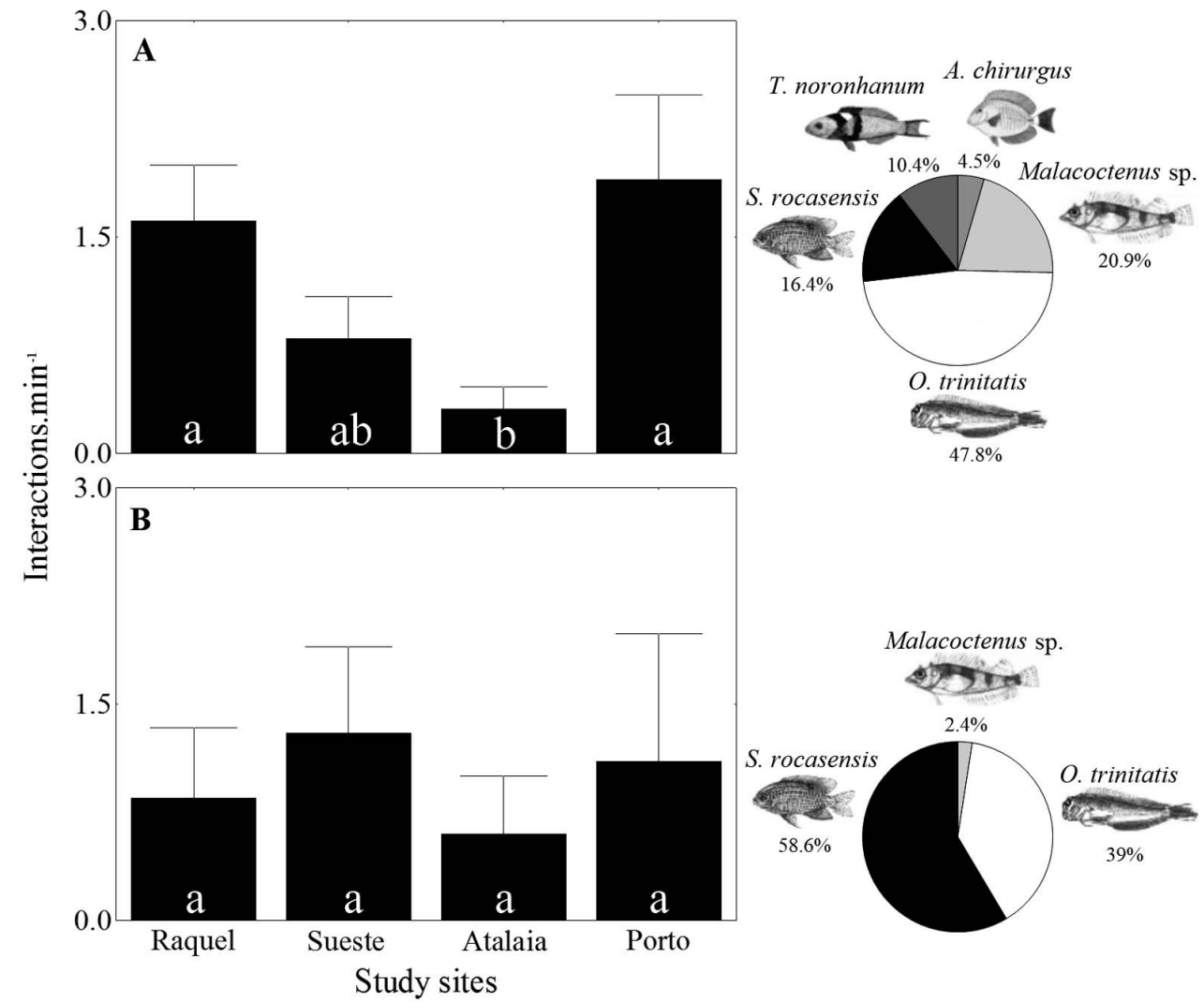

Fig. 6. - Rate of intruder-directed (A) and resident-directed (B) agonistic interactions (mean \pm SE) from four study sites. For each type of interaction, percent contribution of intruder species is indicated. Significant differences between sites (i.e. between columns) are assigned by different letters, independently for each panel. 
towards conspecific intruders, Malacoctenus sp. and S. rocasensis (Fig. 6A). Within the rate of resident-directed agonistic interactions, no significant differences were observed among sites (ANOVA; $\mathrm{F}_{3,39}=0.23$; $\mathrm{p}>0.05$ ) Fig. 6B). In $97 \%$ of the occurrences, resident $O$. trinitatis received aggressive displays from $S$. rocasensis and conspecific individuals (Fig. 6B).

Neither intruder-directed $\left(\mathrm{r}^{2}=0.03 ; \mathrm{p}>0.05\right)$ nor resident-directed interactions $\left(\mathrm{r}^{2}=0.01 ; \mathrm{p}>0.05\right)$ correlated significantly with total length of individuals. Further, though intruder-directed interactions did not show a significant relation with territory size $\left(r^{2}=0.07\right.$; $\mathrm{p}>0.05)$, resident-directed interactions were more commonly observed inside larger territories $\left(r^{2}=0.18\right.$; $\mathrm{p}<0.01$ ). Also, agonistic interactions (both types pooled) were lower at sites with higher structural complexity $\left(\mathrm{r}^{2}=0.10 ; \mathrm{p}<0.05\right)$.

\section{DISCUSSION}

\section{Relationship between fish density and habitat fea- tures}

The density of $O$. trinitatis observed in the present study concurs with densities reported for this species and for the related $O$. atlanticus on tropical rocky and coral reefs (e.g. Nursall 1981, Mendes 2007). The available literature suggests a high variability in the density of the latter species among different Caribbean sites, ranging from 0.29 ind. $\mathrm{m}^{-2}$ at Punta de Betín (Rylander and Koster 1982) to 2.2 ind. $\mathrm{m}^{-2}$ at Barbados (Labelle and Nursall 1992). This somewhat high variability may be attributed to stochastic fluctuations in recruitment (Sale 1978, Sale and Douglas 1984), but also to geographical variations in the availability of space and suitable substrate (Labelle and Nursall 1992). In the present study, local variation in fish density (i.e. among sites separated by few kilometres) was observed.

Local differences in the density of $O$. trinitatis among the four study sites may be attributed to differences in habitat characteristics, which eventually influenced territory size (see below). Although rugosity measures were similar across all sites, this factor had a significant positive effect on the distribution of this blenny, given that individuals were always observed near to, or associated with, small caves and crevices. In fact, presence of crevices seems to be a central habitat requisite for this species, and tight correlations between blennies and crevices are well documented (e.g. Rylander and Koster 1982, Bath 1990, Labelle and Nursall 1992, Mendes 2006, 2007). As complementary evidence, during two years of field experience in the study area, $O$. trinitatis was never observed at low-complexity unconsolidated sites, and was very rare even at the rocky reef-sand ecotone. A similar correlation was previously observed in a small shallow reef (Medeiros et al. 2010a), supporting the prominent habitat selectivity of this species.

Contrary to initial expectations, benthic composition was a somewhat poor determinant of $O$. trinitatis density (see PCA results), and though substrate diversity was significantly higher at sites with high fish density, only indirect assumptions on the influence of single benthic components are possible. For example, samples with a high contribution from turf and coralline algae showed higher fish densities, whereas samples with a high contribution from live coral and sand showed lower densities. Presence of turf algae inside the territories of these blennies is likely to be related to their feeding preferences (see below), but since this item is highly abundant at all sites (a common feature of south Atlantic reefs; e.g. Ferreira et al. 2004, Floeter et al. 2005, Medeiros et al. 2010a), it seems not to be a limiting factor on the abundance of $O$. trinitatis. Instead, as mentioned above, presence of crevices is particularly more important. An investigation on the required surface area of turf algae to supply each individual blenny is, however, necessary and should elucidate this (but see Nursall [1981], who suggested that the territory should include more resources than the minimum required for survival). Nonetheless, optimal sites seem to be those located in shallow depths (Rangel and Mendes 2009) with a complex rocky terrace covered by a sufficient percentage of turf cover, with a low vertical profile (low macroalgae cover), and low quantities of coral and sand. In fact, hiding places and high-quality food seem to be common prerequisites for all small territorial herbivores (e.g. Low 1971, Ebersole 1977, Labelle and Nursall 1992, Letourneur 1992, Haley and Müller 2002, Medeiros et al. 2010b), given the disadvantageous net costs of defending low-quality territories (see reviews by Dill 1978 and Ebersole 1980).

\section{Feeding behaviour}

Randall (1996) reported that turf algae were the only preferred benthic item of $O$. trinitatis and filamentous algae were the primary food item of $O$. atlanticus. Given the high abundance of turf algae at all study sites (covering a mean of $39.4 \%$ of the benthic surface), food is unlikely to be a limiting factor for this species. Roberts (1987), studying Pacific blennies and damselfishes, also suggested that the presence of algae outside territories was evidence that food was not a limiting factor for these fishes. Our observations suggest that turf algae are also highly abundant in unoccupied interstitial spaces outside the territories of $O$. trinitatis and at the sand-reef ecotone, further supporting this hypothesis. On the other hand, crevice availability seems to be more limited. In fact, blennies were observed associated with substrate of high structural complexity with somewhat low turf cover, but never in turf-rich sites lacking crevices.

Confirming the hypothesis, bite rate decreased with an increase in size of blennies, suggesting an ontogenetic variation in energy demand, which is expected to be higher for developing juveniles (Hernaman et al. 2009). Medeiros et al. (2010b) studied the feeding habits of the juveniles of two territorial damselfishes and found similar evidence of ontogenetic shifts in the bite rate of these fishes, but these reports remain somewhat scarce and underreported for most reef fish families.

Feeding rate peaked between 1 and 2 pm and was concentrated in the afternoon. Nursall (1981), studying 
O. atlanticus, reported that individuals of this species also concentrated their feeding in the afternoon period and employed time-minimized strategies. Our observations support the findings of Mendes (2006), who stated that individuals alternate between fast foraging and resting inside the crevices, as a means of minimizing predation risk during feeding. Nursall (1981) also stated that $O$. atlanticus allocated $8.5 \%$ of its time to feeding. Interestingly, time estimates from unpublished video recordings of several individuals showed that $O$. trinitatis individuals allocated $8.83 \%$ of their time to feeding. Furthermore, these values are considerably lower than those recorded for other reef fishes (e.g. Jones and Norman 1986, Bonaldo et al. 2005, Meekan et al. 2010), supporting Nursall's affirmation that Ophioblennius species are highly efficient time-minimizers.

\section{Territory size and agonistic behaviours}

Territory size of $O$. trinitatis $\left(0.79 \mathrm{~m}^{2}\right)$ was considerably smaller than those reported by Rylander and Koster (1982) (between 1.17 and $2.41 \mathrm{~m}^{2}$ ), but slightly larger than those reported for $O$. atlanticus by Nursall (1977) $\left(0.5 \mathrm{~m}^{2}\right)$. Territories defended by $O$. trinitatis showed local variation in size, being larger at sites with lower fish densities (compare Figs $2 \mathrm{a}$ and 5a). As hypothesized, these differences suggest that territory size increases at low-density sites (a density-dependent mechanism). In addition, though food does not seem to influence territory size (see above), it seems that fish need to compensate for residing on lower quality substrates by increasing their territory coverage. Although we found little evidence that food determined territory size, availability of hiding places seems to be a major determinant (see Rylander and Koster 1982). Therefore, we highlight the importance of structural heterogeneity for site-attached fishes, as also acknowledged for several other reef fishes (e.g. McCormick 1994, Friedlander and Parrish 1998, Jones and Syms 1998). High-quality territories (sites of high structural complexity) are also important during reproduction, being a prerequisite during mate selection by females (Labelle and Nursall 1992).

Larger individuals of $O$. trinitatis defended larger territories, as previously observed for other territorial fishes (Ebersole 1980, Rylander and Koster 1982, Medeiros et al. 2010b). Our findings suggest that territory size is driven by hierarchical and life-stage forces. Therefore, to achieve typical territorial adult habits, recruits need to first take up interstitial space (i.e. unoccupied area between territories) and gradually increase its area during their development (see Nursall 1977, Robertson 1984). Nonetheless, field experimental studies are necessary to elucidate these processes.

Regardless of the implications concerning local differences in territory size, optimal territories should be those with the smallest possible area, but including a sufficient food supply and suitable hideaway places. As acknowledged by Rylander and Koster (1982), these territories should increase the fitness of residents by reducing the risk of foraging away from shelter and the energy spent in territory defence.
Resident $O$. trinitatis individuals responded differently to fishes recorded inside their territories (i.e. intruders), given that common species such as $H$. parra, T. noronhanum, A. saxatilis and A. chirurgus were rarely or never attacked. On the other hand, S. rocasensis, Malacoctenus sp. and conspecific individuals were those most subjected to intruder-directed agonistic interactions. Stegastes rocasensis is a highly territorial species with microhabitat and food preferences similar to those of $O$. trinitatis (Souza et al. 2010). Malacoctenus sp., however, has different food habits but is highly site-attached, sharing substrates with $O$. trinitatis (Rangel and Mendes 2009), though sandy areas are also common microhabitats for these fish (author's personal observation). Therefore, conspecifics, $S$. rocasensis and, to a smaller extent, Malacoctenus sp., were the most important competitors of $O$. trinitatis. Focusing agonistic displays towards potential intruders should be energy-efficient, given the unnecessary cost of territory defence towards non-competitive species, which are more often tolerated inside territories (Warner and Hoffman 1980).

Agonistic interactions towards resident $O$. trinitatis were mostly made by $S$. rocasensis and conspecific individuals. In general, for each agonistic attack directed towards an $S$. rocasensis individual, resident $O$. trinitatis received over 3.5 counterattacks. Thus, $S$. rocasensis is a far more aggressive species than $O$. trinitatis. Mendes (2006) and Nursall (1977) reported a low frequency of both intra- and interspecific agonistic interactions for $O$. trinitatis and $O$. atlanticus, respectively, but Rylander and Koster (1982) stated that interspecific agonistic interactions between $O$. atlanticus and two damselfishes were common.

Evidence of size-dependent territory dominance was not observed in the present study. In fact, among conspecifics, residents were more successful at defending territories than intruders were at overtaking them, regardless of individual size. A similar mechanism was acknowledged by Picciulin et al. (2006), who stated that resident territorial gobies had a greater chance of maintaining their territories when attacked by an intruder conspecific, regardless of size.

Fish defending larger territories were subject to higher levels of aggressive interactions from intruders, supporting the findings of Rylander and Koster (1982). Given the obvious dislocation constraints of defending distant borders, larger territories are more vulnerable to intruders. Furthermore, agonistic interactions are expected to be higher at complex sites due to higher fish densities (McCormick 1994), but in the present study agonistic interactions were higher at low-complexity sites. This was due to the increased competition for refuge places (i.e. crevices), which are scarce at lowcomplexity sites.

Despite its aggressive territorial behaviour, $O$. trinitatis showed some degree of tolerance towards conspecifics. Densities of 2.5 and 3 ind. $\mathrm{m}^{-2}$ were frequently observed and, in many cases, without intraspecific agonistic interactions, suggesting a possible intraspecific symbiotic sharing of territories (see Robertson and Polunin 1981). Since food did not seem to be a 
limiting factor for the abundance of these blennies, the benefits of symbiotic sharing might overcome the net costs of co-habiting with potential competitors. These benefits appear to be the improved territory defence (given that the task is split among multiple individuals) and the underlying reduced energy cost of employing agonistic displays (Robertson and Polunin 1981, Norman and Jones 1984, Foster 1985, Iguchi and Abe 2002). Evidence of symbiotic sharing has been previously acknowledged for blennids (e.g. Roberts 1987, Townsend and Tibbetts 2004). Furthermore, Mendes (2006) recorded, at several occasions, up to six 'tolerating' Ophioblennius individuals inhabiting a $1 \mathrm{~m}^{2}$ area. Future studies, however, should elucidate whether territorial sharing is not simply a temporary sex-related process (i.e. sexual aggregation or harem formation).

\section{ACKNOWLEDGEMENTS}

We are indebted to A. M. A. Medeiros and R. G. Grempel for assistance during field work, and the staff of Instituto Chico Mendes de Conservação da Biodiversidade (ICMBio) for providing logistic support and accommodation on the island. The Brazilian Conselho Nacional de Desenvolvimento Científico e Tecnológico $(\mathrm{CNPq})$ provided financial support.

\section{REFERENCES}

Bath H. 1990. Blenniidae. In: Quero J.C., Hureau J.C., Karrer C. et al. (eds), Check-list of the fishes of the eastern tropical Atlantic (CLOFETA). SEI UNESCO, Lisboa, $1490 \mathrm{pp}$

Bonaldo R.M., Krajewski J.P., Sazima I. 2005. Meals for two: foraging activity of the butterflyfish Chaetodon striatus (Perciformes) in southeast Brazil. Braz. J. Biol. 65: 211-215. http://dx.doi.org/10.1590/S1519-69842005000200004

Dill L.M. 1978. An energy-based model of optimal feeding-territory size. Theor. Popul. Biol. 14: 396429. http://dx.doi.org/10.1016/0040-5809(78)90016-3

Ebersole J.P. 1977. The adaptive significance of interspecific territories in the reef fish, Eupomacentrus leucostictus. Ecology 58: 914-920.

http://dx.doi.org/10.2307/1936228

Ebersole J.P. 1980. Food density and territory size: An alternative model and a test on the reef fish (Eupomacentrus leucostictus). Am. Nat. 115: 492-509. http://dx.doi.org/10.1086/283576

Eston V.R., Migotto A.E., Oliveira-Filho E.C., et al. 1986. Vertical distribution of benthic marine organisms on rocky coasts of the Fernando de Noronha Archipelago (Brazil). Bol. Inst. Oceanogr. 34: 37-53.

Ferreira C.E.L., Floeter S.R., Gasparini J.L., et al. 2004. Trophic structure patterns of Brazilian reef fishes: a latitudinal comparison. J. Biogeogr. 31: 1093-1106. http://dx.doi.org/10.1111/j.1365-2699.2004.01044.x

Floeter S.R., Gasparini J.L. 2000. The southwestern Atlantic reef fish fauna: composition and zoogeographic patterns. J. Fish Biol. 56: 1099-1114. http://dx doi.org/10.1111/j.1095-8649.2000.tb02126.x

Floeter S.R., Gasparini J.L. 2001. The Brazilian endemic reef fishes. Coral Reefs 19: 292. http://dx.doi.org/10.1007/s003380000097

Floeter S.R., Behrens M.D., Ferreira C.E.L., et al. 2005. Geographical gradients of marine herbivorous fishes: patterns and processes. Mar. Biol. 147: 1435-1447. http://dx.doi.org/10.1007/s00227-005-0027-0

Foster S.A. 1985. Group foraging by a coral reef fish: a mechanism for gaining access to defended resources. Anim. Behav. 33: $782-792$. http://dx.doi.org/10.1016/S0003-3472(85)80011-7

Friedlander A.M., Parrish J.D. 1998. Habitat characteristics affecting fish assemblages on a Hawaiian coral reef. J. Exp. Mar.
Biol. Ecol. 224: 1-30 http://dx.doi.org/10.1016/S0022-0981(97)00164-0

Guimarães R.Z.P., De Bacellar A.C.L.H. 2002. Review of the Brazilian species of Paraclinus (Teleostei: Labrisomidae), with descriptions of two new species and revalidation of Paraclinus rubicundus (Starks). Copeia 2: 419-427.

http://dx.doi.org/10.1643/0045-8511(2002)002[0419:ROTBS $\mathrm{O}] 2.0 . \mathrm{CO} ; 2$

Haley M.P., Müller C.R. 2002. Territorial behaviour of beaugregory damselfish (Stegastes leucostictus) in response to egg predators. J. Exp. Mar. Biol. Ecol. 273: 151-159. http///dx.doi.org/10.1016/S0022-0981(02)00144-2

Hernaman V., Probert P.K., Robbins W.D. 2009. Trophic ecology of coral reef gobies: interspecific, ontogenetic, and seasonal comparison of diet and feeding intensity. Mar. Biol. 156: 317-330. http://dx.doi.org/10.1007/s00227-008-1085-x

Humann P., DeLoach N. 2002. Reef fish identification: Florida, Caribbean, Bahamas. New World Publications, Miami.

Iguchi K., Abe S. 2002. Territorial defense of an excess food supply by an algal grazing fish, ayu. Ecol. Res. 17: 373-380. http://dx.doi.org/10.1046/j.1440-1703.2002.00495.x

Ivlev V.S. 1961. Experimental ecology of the feeding of fishes. Yale University Press, New Haven.

Jones G.P., Norman M.D. 1986. Feeding selectivity in relation to territory size in a herbivorous reef fish. Oecologia 68: 549-556. http://dx.doi.org/10.1007/BF00378770

Jones G.P., Syms C. 1998. Disturbance, habitat structure and the ecology of fishes on coral reefs. Aust. J. Ecol. 23: 287-297. http://dx.doi.org/10.1111/j.1442-9993.1998.tb00733.x

Kohler K.E., Gill S.M. 2006. Coral Point Count with Excel extensions (CPCe): a visual basic program for the determination of coral and substrate coverage using random point count methodology. Comput. Geosci. 32: 1259-1269. http://dx.doi.org/10.1016/j.cageo.2005.11.009

Labelle M., Nursall J.R. 1985. Some aspects of the early life history of red lip blenny, Ophioblennius atlanticus macciureii (Pisces: Blenniidae). Copeia 1985: 39-49. http://dx.doi.org/10.2307/1444788

Labelle M., Nursall J.R. 1992. Population biology of the redlip blenny, Ophioblennius atlanticus macclurei (sylvester) in Barbados. Bull. Mar. Sci. 50: 186-204.

Lehner P.N. 1996. Handbook of ethological methods. University Press, Cambridge.

Letourneur Y. 1992. Spatial and temporal variability in territoriality of a tropical benthic damselfish on a coral reef (Réunion Island). Env. Biol. Fish. 57: 377-391. http://dx.doi.org/10.1023/A:1007658830339

Low R.M. 1971. Interspecific territoriality in a pomacentrid reef fish, Pomacentrus flavicauda Whitley. Ecology 52: 648-654. http://dx.doi.org/10.2307/1934153

Luckhurst B.E., Luckhurst K. 1978. Analysis of the influence of substrate variables on coral reef fish communities. Mar. Biol. 49: 317-323. http://dx.doi.org/10.1007/BF00455026

Marraro C.M., Nursall J.R. 1983. The reproductive periodicity and behaviour of Ophioblennius atlanticus (Pisces: Blenniidae) at Barbados. Can. J. Zool. 61: 317-325. http://dx.doi.org/10.1139/z83-042

McCormick M.I. 1994. Comparison of field methods for measuring surface topography and their associations with a tropical reef fish assemblage. Mar. Ecol. Prog. Ser. 112: 87-96. http://dx.doi.org/10.3354/meps112087

Medeiros P.R., Grempel R.G., Souza A.T., et al. 2010a. Nonrandom reef use by fishes at two dominant zones in a tropical, algal-dominated coastal reef. Environ. Biol. Fish. 87: 237-246. http://dx.doi.org/10.1007/s10641-010-9593-1

Medeiros P.R., Souza A.T., Ilarri M.I. 2010b. Habitat use and behavioural ecology of the juveniles of two sympatric damselfishes (Actinopterygii: Pomacentridae) in the south-western Atlantic Ocean. J. Fish Biol. 77: 1599-1615. http://dx.doi.org/10.1111/j.1095-8649.2010.02795.x

Meekan M.G., Kuerthy C., McCormick M.I. et al. 2010. Behavioural mediation of the costs and benefits of fast growth in a marine fish. Anim. Behav. 79: 803-809. http://dx.doi.org/10.1016/j.anbehav.2009.12.002

Mendes L.F. 2006. História natural dos amborés e peixes-macaco (Actinopterygii, Blennioidei, Gobioidei) do Parque Nacional Marinho do Arquipélago de Fernando de Noronha, sob um enfoque comportamental. Rev. Bras. Zool. 23: 817-823. http://dx.doi.org/10.1590/S0101-81752006000300029 
Mendes L.F. 2007. Ophioblennius trinitatis (Pisces: Blenniidae) from the oceanic archipelagos of São Pedro e São Paulo, Fernando de Noronha and Atol das Rocas. Braz. J. Oceanogr. 55: 63-65. http://dx.doi.org/10.1590/S1679-87592007000100008

Morgan I.E., Kramer D.L. 2004. The social organization of adult blue tangs, Acanthurus coeruleus, on a fringing reef, Barbados, West Indies. Env. Biol. Fish. 71: 261-273. http://dx.doi.org/10.1007/s10641-004-0299-0

Moura R.L., Figueiredo J.L., Sazima I. 2001. A new parrotfish (Scaridae) from Brazil, and revalidation of Sparisoma amplum (Ranzani, 1842), Sparisoma frondosum (Agassiz, 1831), Sparisoma axillare (Steindachner, 1878) and Scarus trispinosus (Valenciennes, 1840). Bull. Mar. Sci. 68: 505-524.

Muss A., Robertson D.R., Stepien C.A., et al. 2001. Phylogeography of Ophioblennius: the role of ocean currents and geography in reef fish evolution. Evolution 55: 561-572. http://dx.doi.org/10.1111/j.0014-3820.2001.tb00789.x http://dx.doi.org/10.1554/0014-3820(2001)055[0561:POOTR $\mathrm{O}] 2.0 . \mathrm{CO} ; 2$

Norman M.D., Jones G.P. 1984. Determinants of territory size in the pomacentrid reef fish, Parma victoriae. Oecologia 61: 60-69. http://dx.doi.org/10.1007/BF00379090

Nursall J.R. 1977. Territoriality in redlip blennies, Ophioblennius atlanticus (Pisces: Blenniidae). J. Zool. 182: 205-223. http://dx.doi.org/10.1111/j.1469-7998.1977.tb04156.x

Nursall J.R. 1981. The activity budget and use of territory by a tropical blenniid fish. Zool. J. Linn Soc-Lond. 72: 69-92. http://dx.doi.org/10.1111/j.1096-3642.1981.tb01652.x

Nursall J.R. 1989. Buoyancy is provided by lipids of larval redlip blennies, Ophioblennius atlanticus (Teleostei: Blenniidae). Copeia 1989: 614-621 http://dx.doi.org/10.2307/1445488

Nursall J.R., Turner L. 1985. The liver supports metamorphosis in the Caribbean reef blenniid, Ophioblennius atlanticus. Proc. 5th Int. Cor. Reef Symp. 5: 457-462.

Picciulin M., Sebastianutto L., Costantini M. et al. 2006. Aggressive territorial ethogram of the of the red-mouthed goby, Gobius cruentatus (Gmelin, 1789). Electron. J. Ichthyol. 2: 38-49.

Preskitt L.B., Vroom P.S., Smith C.M. 2004. A rapid ecological assessment (REA) quantitative survey method for benthic algae using photoquadrats with scuba. Pac. Sci. 58: 201-209. http://dx.doi.org/10.1353/psc.2004.0021

Randall J.E. 1996. Caribbean reef fishes. T. F. H. Publications Inc., Hong Kong.

Rangel C.A. Mendes L.F. 2009. Review of blenniid fishes from Fernando de Noronha Archipelago, Brazil, with description of a new species of Scartella (Teleostei: Blenniidae). Zootaxa. 2006: 51-61.

Roberts C.M. 1987. Experimental analysis of resource sharing between herbivorous damselfish and blennies on the Great Barrier Reef. J. Exp. Mar. Biol. Ecol. 111: 61-75.

http://dx.doi.org/10.1016/0022-0981(87)90020-7

Robertson D.R. 1984. Cohabitation of competing territorial damselfishes on a Caribbean coral reef. Ecology 65: 1121-1135. http://dx.doi.org/10.2307/1938320

Robertson D.R., Polunin N.V.C. 1981. Coexistence: symbiotic sharing of feeding territories and algal food by some coral reef fishes from the Western Indian Ocean. Mar. Biol. 62: 185-195. http://dx.doi.org/10.1007/BF00388182

Rocha L.A. 2004. Mitochondrial DNA and color pattern variation in three western Atlantic Halichoeres (Labridae), with the revalidation of two species. Copeia 2004: 770-782. http://dx.doi.org/10.1643/CG-04-106

Rocha L.A., Rosa R.S. 2001. Halichoeres brasiliensis (Bloch, 1791), a valid wrasse species (Teleostei: Labridae) from Brazil, with notes on the Caribbean species Halichoeres radiatus (Linnaeus, 1758). Aqua J. Ichthyol. Aqua. Biol. 4: 161-166.

Rylander M.K., Koster F. 1982. Observations on the biology of the redlip blenny Ophioblennius trinitatis (Pisces: Blenniidae) on the Colombian coast of the Caribbean. An. Inst. Invest. Mar. Punta Betin. 12: 105-115.

Sale P.F. 1978. Coexistence of coral reef fishes, a lottery for living space. Env. Biol. Fish. 3: 85-102. http://dx.doi.org/10.1007/BF00006310

Sale P.F., Douglas W.A. 1984. Temporal variability in the community structure of fish on coral patch reefs and the relation of community structure to reef structure. Ecology 65: 409-422. http://dx.doi.org/10.2307/1941404

Sokal R.R., Rohlf F.J. 1995. Biometry. W.H. Freeman and Company, New York.

Souza A.T., Ilarri M.I., Rosa I.L. 2010. Habitat use, feeding and territorial behavior of a Brazilian endemic damselfish Stegastes rocasensis (Actinopterygii: Pomacentridae). Env. Biol. Fish. 91: 133-144. http://dx.doi.org/10.1007/s10641-010-9765-z

Townsend K.A., Tibbetts I.R. 2004. The ecological significance of the combtoothed blenny in a coral reef ecosystem. J. Fish Biol. 65: $77-90$ http://dx.doi.org/10.1111/j.0022-1112.2004.00426.x

Warner R., Hoffman S.G. 1980. Population density and the economics of territorial defense in a coral reef fish. Ecology 61: 772-780.

http://dx.doi.org/10.2307/1936747 